E., 'Individual traits and morbidity in a Swedish rural population', Acta Psychiatrica et Neurologica Scandinavica, Supplement, 100; Kaneko, Z., 'Care in Japan', in Howells, J. G. (ed), Modem Perspectives in the Psychiatry of Old Age, Brunner/ Mazel, New York; Kay, D. W. K., Beamish, P. and Roth, M., 'Old age mental disorders in Newcastle-upon-Tyne. Part I. A study of prevalence', British Journal of Psychiatry, I10 ( 1964 ), I 46-1 58; Nielsen, J., 'Geronto-psychiatric periodprevalence investigation in a geographically delimited population', Acta Psychiatrica Scandinavica, 38 (1962), 307-330; Primrose, E. J. R., Psychological Illness: A Community Study, Charles C. Thomas, Springfield, Il.

17 Report on the Royal College of Physicians by the College Committee on Geriatrics, op. cit.; Report of a World Health Organisation Scientific Group on Senile Dementia, Dementia in Later Life: Research and Action, Technical Report Series, 730, World Health Organisation, Geneva, 1986.

I 8 Kay et al., I 964 , op. cit.

19 Report of the Royal College of Physicians by the College Committee on Geriatrics, op. cit.; Report of a World Health Organisation Scientific Group on Senile Dementia, op. cit.

20 Williamson, J., Stockoe, I. H., Gray, S., Fisher, M., Smith, A., McGhee, A. and Stephenson, E., 'Old people at home: Their unreported needs', Lancet, i (1964), I I 7-I I 20; Harwin, B., 'Psychiatric morbidity among the physically impaired elderly in the community', in Wing, J. K. and Hafner, V. F. (eds). Roots of Evaluation: The Epidemiological Basis for Planning Psychiatric Services, Oxford University Press, Oxford, I979.

2 I Gurland, B. J. and Wilder, D. E., 'The CARE revisited: development of an efficient, systematic clinical assessment', Journal of Gerontology, 39 (1984), 129-137.

Health Care Research Unit, University of Newcastle upon Tyne

\title{
Religion and Ageing
}

\section{Mannes Tidmarsh}

Leo E. Missine and Judy Willeke-Kay, 'Reflections on the meaning of life in older age', Journal of Religion and Aging, I (1985), 43-56.

The authors ask the question, 'Where is the ageing person to find meaning in a culture that values work and youth so highly?'. They propose to use Frankl's theory (based on his concentration camp experience) to explore the issue. They argue that Frankl's principles, based on the view that human behaviour is related to the values in which a person believes and his/her search for meaning, are readily applicable to the needs and concerns of the elderly. Indeed, they suggest that the western world is a kind of concentration camp for many elderly people.

Having pointed out that Frankl found people often had an inner strength that enabled them to survive terrible situations, they go on to apply four fundamental principles of his theory to the behaviour of older people: 
(a) Meaning of life is created by each person through the choices he/she makes. Everyone has the freedom to make these choices and must accept responsibility for them.

Frankl observed that the one freedom that could not be taken away in the camps was that of choosing one's attitude in any given set of circumstances. The authors argue that the aged, facing physical and emotional suffering, have the same freedom to choose and thus maintain their own dignity.

(b) Meaning of life is based on the values in which a person believes.

Frankl sees meaning as conveyed by three types of value; creative, experimental and attitudinal. Though retirement may undermine the first and ill-health the second the authors argue that the aged still have the freedom to choose their response to the challenge of age. How a person faces loss and suffering could be the highest value which gives meaning to life.

(c) Meaning of life is found not in what a person expects of life but in what life expects of him/her.

For Frankl the response to lack of aim or sense in life lies in 'right action and right conduct'. Old people, say the authors, are, like everyone else, responsible for the answers they give to the questions life asks them. If what has passed has been good old people must continue it; if it has been unjust they must do what they can to correct it.

(d) Meaning of life is a combination of ultimate meaning and many provisional meanings.

The comprehension of infinite meaning in one's life is preceded by provisional or short-term experiences which will be valid for a certain time and place but need to be integrated with the ultimate meaning. Old age is the ideal time for achieving this integration.

The second part of the paper consists of a series of brief interviews with older people concerning what gives meaning to their lives and the authors' reflections on these sessions. They conclude that most difficulties are related to meaning of life including: 'adjustments to the loss of work, the loss of mate... problem of chronic physical suffering, prospect of institutionalisation...inevitability of death'. All those interviewed stressed the importance of experiential values, especially emphasising the importance of love: 'the discovery of meaning in later life takes place in relation to others'. The death of a loved one is the worst thing that can happen to them. The authors argue from this that 
the most important thing we can do on behalf of older people is to encourage a lifestyle that does not isolate them.

In their conclusions Missine and Willeke-Kay point out that Frankl saw his theory as activistic and considered that 'success' in later age lay in attacking problems. But not all do face problems thus: some hide from past mistakes or fear the future or the reality of death. Such people need support and encouragement to see and take choices that remain open to them. When we find an old person who can find no definitive meaning in life we must ask whether the distress may be spiritual rather than emotional. A firm belief in God helps to establish faith in an ultimate meaning, but the adult whose belief is uncertain or whose faith is weak can be helped, the authors suggest, by a reminder of the continuing potential for change under God's grace.

\section{COMMENT}

In spite of a somewhat exhortatory tone this paper raises an important issue and finds, in Frankl's analysis, a potentially fruitful approach to it. Unfortunately their own application of it is poorly reported; we are not given sufficient information about the interviews they cite and a number of immediately obvious questions remain unasked.

William M. Clements, 'Aging and the dimensions of spiritual development', Journal of Religion and Aging, 2 (1986), $127^{-1} 3^{6}$.

Clements begins by identifying four basic presuppositions to a discussion of spiritual development: (a) that there is something called 'the human spirit', (b) that this spirit may be considered to have both a personal and a corporate dimension, (c) that the spirit enjoys personal continuity in time and that self-consciousness may emerge at various life-cycle points, (d) that the human spirit, in both its dimensions, can both grow and regress.

He goes on to identify two factors out of many that may contribute to spiritual development: memory and prolepsis. Memory is essential for personal identity and it is also the collagen, the connective tissue, of civilisation: it is what gives humanity a sense of continuity. The memories that contribute to identity need not be of personal experiences, they can be historical, communal memories: ' who I am today is determined not only by what I have directly experienced myself but also by those precious memories that have been transmitted to me'. Present identity is also dependent on the accounts of history that a person has absorbed. 
The formative elements of memory are not always available to conscious awareness and an outsider of long acquaintance may observe influences on our identity that we could not ourselves trace. This is why living in a tradition or community is important (especially for old people) because the community memory may help identify influences that, over time, individuals may have lost sight of.

Prolepsis, the assumption of a future development as already existing, can exist in old age, says Clements, only when there is a hopeful vision of the future which gives warrant for spiritual development. For the Christian, prolepsis is most clearly embodied in the Eucharist but, all too often, 'the prolepsis that exists in old age is that of regression or stagnation. Our society does not have a vision of old age as a time of spiritual development'.

Clements goes on to argue that part of the reason for this lack of a vision lies in our view of time. He goes on to compare two views of time. The commonly held one sees it as a line of continuity running through from the past via the present into the future, like a ball of string rolled out. This leads us to see history as referring only to the relatively distant past and the future as far reaching. By contrast Clements sees time rather as a series of photographs taken with a polaroid time-lapse camera, each image discreet yet linked to those adjoining. He maintains that whereas the former view inhibits development in old age by its emphasis on long time-spans and continuity, the latter sees development as taking place, even in old age, in the transition from one moment to the next and so always possible.

In the second part of the paper Clements makes two practical suggestions about what the churches may do to foster spiritual development. They should put before their members images of people who have achieved this in the past and they should promote the development of religious gerontology in theological colleges and seminaries. Clements develops this point in some detail, looking at ways in which different disciplines might contribute and suggesting practical measures to promote cooperation.

\section{COMMENT}

The first part of this paper offers several fresh insights and an interesting hypothesis and the second makes an important proposal for a new development in gerontology, but the two parts seem to lie uneasily together and each needs fuller treatment than it receives here to make its impact. Certainly, both deserve further attention, and the suggestion that there should be closer co-operation between gerontologists, theo- 
logians and pastors may be seen as particularly apt at a time when new initiatives in teaching and research in gerontology are getting under way in this country.

Christian Council on Ageing, Northamptonshire

\section{Work and Retirement}

\section{Chris Phillipson}

Malcolm H. Morrison, 'Work and Retirement in the Aging Society', Daedalus, 115 ( 1986 ), 269-294.

Malcolm Morrison's essay appears in a collection, sponsored by the Journal of the American Academy of Arts and Sciences, devoted to the theme of an Ageing Society. The focus, perhaps inevitably, is on the American scene, but there are some excellent individual contributions which deserve a wide readership.

Morrison's essay attempts to draw conclusions from three principle areas of research and debate: first, the findings from research on attitudes towards retirement; secondly, perspectives on the history of retirement; thirdly, discussions on the economic consequences of retirement policies.

On the first area, Morrison suggests contradictory forces are at work in public attitudes and perceptions about retirement. On the one hand, there appears to be increasing acceptance of retirement as a social institution; on the other hand, significant numbers of retirees still feel deprived of significant roles which allow them to maintain a presence in society.

The historical research, according to Morrison, points to how retirement became institutionalised through policies aimed at increasing job security, replacing 'energetic' for 'worn-out' employees, and providing income security for superannuated workers. Ultimately, it was to be an economic crisis (in the r 930 ) which gave the decisive push to the emergence of this social institution.

Thirdly, there is the question of the implications of reduced labourforce participation. Here, the author errs on the side of the pessimists: older people, he suggests, are expensive (consuming, at present, $30 \%$ of the annual federal budget) and non-productive (both in waged and unwaged terms). In the long term, he argues, this growth in the non-waged sector cannot be sustained. Morrison draws upon two main arguments to strengthen his case. First, retirement policies were developed at a time when there were relatively few older people. This situation has clearly changed and with the current emphasis on early and complete retirement, significant economic problems could develop 